\title{
Trade Study of Population Age Groups for a Clinical Trial in Attention Deficit Hyperactivity Disorder
}

\author{
Dalton B. Lovins ${ }^{0000-0002-5875-4871}$ and Robert A. Lodder ${ }^{0000-0001-6133-7561}$ \\ College of Pharmacy, Todd Building, 789 S. Limestone, University of Kentucky, Lexington, KY 40536
}

\begin{abstract}
ADHD is a neurodevelopmental disorder characterized by difficulty paying attention, impulsivity, and hyperactivity that is treated by an array of different modalities in order to decrease functional impairment. Despite the variety of available pharmacologic treatment options and their widespread use, there still remains a strong need to create innovative therapies. Game Based Therapy (GBT) is a type of cognitive behavioral therapy that seeks to increase the efficacy of currently available pharmacological treatments through improving cognitive deficits and reducing the current dose of such treatments. At the University of Kentucky, a clinical trial was implemented to assess the effects of combining stimulant pharmacotherapy with the popular video game Minecraft as Game Based Therapy on ADHD symptoms in children ages 10-15. However, the low subject recruitment played a large role in the trial failing to produce conclusive data from that site.

This trade study serves to address the difficulties of subject recruitment and determine an optimal population and location for future adoption of the clinical trial. Through statistical analysis of state, national, and survey data it was found that in Lexington, Kentucky, 18-21 year olds are the optimal population for future GBT with pharmacotherapy clinical trials.
\end{abstract}

\section{INTRODUCTION}

Attention deficit hyperactivity disorder (ADHD) is a neurodevelopmental disorder characterized by difficulty paying attention, impulsivity, and hyperactivity ${ }^{1}$ and is the most commonly diagnosed behavioral disorder in children. ${ }^{2}$ ADHD was originally defined in children but is now recognized to persist into adulthood for some patients. Despite this recognition, adult ADHD remains underdiagnosed. ${ }^{3}$ A study using a nationally representative sample of adults in the United States estimated that the prevalence of ADHD in adults was $4.4 \%{ }^{4}$

Importantly, symptom presentation changes over a lifetime in individuals with ADHD and can be associated with different profiles of functional impairment. Symptoms of hyperactivity, impulsivity, and inattention during childhood often result in disruptive behavior at home and in academic impairment at school. In adulthood, symptoms further evolve such that hyperactivity decreases or morphs into more purposeful activity or inner restlessness, whereas 
inattention, disorganization, and impulsivity remain, which can lead to functional difficulties in home, social, and work settings. ${ }^{5,6}$

Appropriate management of adult patients with ADHD is multimodal. Psychoeducation, counseling, supportive problem-directed therapy, behavioral intervention, coaching, cognitive remediation, and couples and family therapy are useful adjuncts to medication management. Concurrent supportive psychosocial treatment or polypharmacy may be useful in treating the adult with comorbid ADHD. ${ }^{3}$

An array of nonpharmacologic and pharmacologic treatments are available for the treatment of ADHD in adults. Nonpharmacologic therapies, such as cognitive behavioral therapy (CBT), dialectical behavioral therapy (DBT), physical exercise, and mindfulness awareness practice, have all been shown to confer benefits in adults with ADHD. ${ }^{3}$ CBT is a model that combines higher-level organization and planning, behavioral skills training, and cognitive restructuring. CBT has been used extensively as a stand-alone therapy and in combination with pharmacotherapy in the treatment of ADHD in adults. ${ }^{7}$ Pharmacologic options include psychostimulants, which have demonstrated the greatest levels of efficacy for treating the core symptoms of ADHD in adults, and nonstimulants, which can be considered when there are concerns related to response, tolerability, or safety with psychostimulants. Despite the variety of available pharmacologic treatment options and their widespread use, there still remains a strong need to create innovative therapies. ${ }^{8}$

Unfortunately, the benefits that do result from stimulant use do not persist after discontinuation and patients with ADHD still suffer from adverse long-term outcomes such as poor academic performance, drug addiction, and criminal behavior to a much greater degree than non-ADHD subjects despite optimal therapy. ${ }^{9}$

The advantages of combining pharmaceutical therapy with behavioral therapy include lower cost, as personnel time with patients is reduced, and reduced doses of pharmaceuticals (50-75\%). Additionally, the benefits of behavior therapy are more likely to carry forward once treatment has stopped. ${ }^{10}$

The possibility of a synergistic effect from combining pharmacological therapy with Game Based Therapy (GBT) for use in ADHD treatment stems from being able to increase the efficacy of currently available pharmacological treatments through improving cognitive deficits and having the ability to reduce the current dose of such treatments. The suggested mechanism for GBT improving ADHD symptoms is that improves the cognitive processes that underlie them. Executive function, a potential intervention target, is a set of top-down mental processes 
that regulate distracting influences and automatic, unproductive behaviors. ${ }^{11}$ As a result, targeting executive function may allow patients to have better self-control.

Another advantage of utilizing video games for combination therapy is the fact that there is a high volume of scenarios upon which to strengthen patients skills. Different scenarios each day throughout treatment periods reduce the training effect and allow the patient to broaden complex thinking skills instead of focusing on memorizing how to complete a specific task.

One study produced by Akili Interactive Labs, Inc. compared the cognitive functions' of neuro-typical children/those that lacked a diagnosis of ADHD with children that were diagnosed with ADHD. Akili uses a technology entitled EVO to evaluate cognitive interference and the potential maintenance of clinical benefit produced from game based therapy in children ages 8-12 with ADHD. EVO is used to assess reaction time, multitasking ability, and sustained effects of game-based therapy after the end of treatment periods. The study found that there was a significant improvement in the reaction time for the children with ADHD, and lacked a statistically significant result for the neurotypical children.

Minecraft is an online video game containing a virtual land where users can create their own worlds and experiences, using building blocks, resources discovered on the site and their own creativity. Minecraft requires its users to apply problem solving, planning, and organizational skills for creative building and exploration. ${ }^{12}$ It offers many levels of difficulty, which allows for adaptation to users with a wide range of cognitive abilities as well as potential for incremental progressions in difficulty as the user's performance improves.

Our previous clinical study utilized the popular online video game, Minecraft, to evaluate its potential for improving executive function in children, ages 10 to 15 , with ADHD. The personalized medicine approach included an individualized treatment regimen consisting of an initial stimulant dose recommendation and schedule of Minecraft activities which were determined by the initial ADHD assessment results of new patients. ${ }^{13}$ The study was designed to create novel training activities that would address both the underlying core executive functions (working memory, inhibition, and cognitive flexibility), as well as executive function skills utilized in school and work settings (planning, time management, self-regulation, sustained attention, organization, goal-directed persistence, and metacognition). One of the overall goals of the trial was to develop a better understanding of the relationship between NICHQ Vanderbilt Assessment scores (an assessment that measures ADHD symptoms as well as the patient's function in everyday life), game aspects of Minecraft, and executive function.

This paper will serve as a trade study ${ }^{14}$ to collect and compare relevant information regarding two different age groups. A trade study (also known as a trade-off study) serves to 
analyze the differentiating factors between two or more systems and identify the most balanced technical solution. Trade studies utilize both quantitative and qualitative measures when determining which solution will produce the optimal outcome. They examine critical factors such as system cost, reliability, maintainability, logistic support, growth potential, and more to improve systematic decisions. For example, if the challenge for an automotive company is to design a vehicle that will bring in the most profit for the company, a trade study can be performed. This allows automotive teams to look into different manufacturing materials, locations for production, fuel-efficiency systems, etc. so that they can create different vehicles, then identify the one with the best profit margin. For a clinical trial, there are many outcome-influencing factors as well. For example, a disease may be location specific, like Ebola, so if an organization were to do a clinical trial in a low-prevalence area, the results of the study may not reflect the entire population.

The initial study ${ }^{13}$ sought to observe the effects of playing Minecraft on executive function in pediatric patients, ages 10-15, with ADHD. The exploratory study used specially designed technological activities to train executive function, working memory, and restraint within the environment of the popular computer game Minecraft. The study attempted to determine whether there is a functional relationship between NICHQ scores, game aspects of Minecraft, and executive function. The primary measures of this study were the changes in NICHQ scores, as measured by a NICHQ questionnaire before and after 4 weeks of therapeutic gaming while simultaneously taking a stimulant type ADHD medication. All study participants were recruited within UK Healthcare in Lexington, Kentucky from October of 2016 to June of 2018 .

The trial studying the 10-15 year old adolescent population in Lexington, Kentucky was launched to determine the possibility of synergistic effects from GBT and pharmaceutical therapy for ADHD. ${ }^{13}$ However, the trial failed to recruit a population large enough to be able to make an accurate scientific conclusion. One major obstacle the study encountered was that you cannot recruit in public schools unless you invest in getting permission. However, university students are readily available, thus it may be easier to conduct a study in the 18-21 year old college student population.

This trade study will address specific risks, benefits, challenges, and future clinical research directions associated with combining pharmacological and GBT for these two different populations. The paper will also reveal the value of reproducing the initial study with the 18-21 year old population as well as address the reasons for low recruitment in the past. In order for the future study to be executed we must meet requirements that include a minimum 16 subject population that is recruitable within two months and an IRB approved population. 
For the two different study groups we will assess 13 different categories that we believe have a significant effect on subject recruitability and/or IRB approval. These categories and the values associated with them will serve as evidence for determining statistical differences between the two age groups. The 13 categories are as follows: transportation, the IRB parent/guardian approval requirement for those under the age of 18, financial need, ADHD rate, population density, population proximity, video game experience, life experience, student/teacher relationship strength as determined by class size, medication therapeutic range, obesity rate, sleeping disorder rate, and anxiety disorder rate. The descriptions of each category are included in our scoresheet here.

STATISTICAL ANALYSIS VALUES ARE IN [BRACKETS]

\begin{tabular}{|c|c|c|}
\hline Category & Adolescents (10-15y) & College Students (18-21y) \\
\hline Transportation" & $\begin{array}{c}{[\mathbf{1 0}]^{1,2}} \\
10 \% \text { availability } \\
\text { Biking/walking distance, } \\
\text { local buses, taxi services, } \\
\text { dependent upon parents } \\
\text { transportation or parent } \\
\text { approval of transportation } \\
\text { form. }\end{array}$ & $\begin{array}{c}{[\mathbf{1 0 0}]^{2,3}} \\
\text { Independent on others for } \\
\text { transportation. } \\
\text { Walking/biking distance, } \\
\text { bus routes, } \\
\text { self-owned vehicle. }\end{array}$ \\
\hline $\begin{array}{l}\text { Parent/Guardian } \\
\text { Approval } \\
\text { Requirement }^{\#}\end{array}$ & $\begin{array}{c}{[\mathbf{0}]^{4}} \\
\text { Required }\end{array}$ & $\begin{array}{c}{[\mathbf{1 0 0}]^{4}} \\
\text { Not required }\end{array}$ \\
\hline Financial Need Rate & $\begin{array}{c}{\left[\mathbf{1 7 . 8 ] ^ { 5 }}\right.} \\
\begin{array}{c}17.8 \% \text { are below the poverty } \\
\text { level }\end{array}\end{array}$ & $\begin{array}{c}{[\mathbf{7 0 . 0}]^{\mathbf{6}}} \\
70 \% \text { of students have debt } \\
\text { after graduation. } \\
\text { On average, } \$ 29,800 \text { owed } \\
\text { after graduation. }\end{array}$ \\
\hline $\begin{array}{l}\text { Population Density } \\
\text { (Lexington, KY) }\end{array}$ & $\begin{array}{c}{[\mathbf{2 1 . 9}]^{7}} \\
\mathrm{n}=16,175 \\
\text { Male: } 8,283 \\
\text { Female: } 7,892 \\
\text { Per square } \mathrm{km} \\
\left(16,175 / 739 \mathrm{~km}^{\wedge} 2\right) \\
=21.9\end{array}$ & $\begin{array}{c}{[\mathbf{2 3 . 9}]^{7}} \\
\mathrm{n}=17,671(18-21) \\
\text { Male: } 8,780 \\
\text { Female: } 8,891 \\
\text { Per square } \mathrm{km}=17671 / 739= \\
{[23.9]}\end{array}$ \\
\hline
\end{tabular}




\begin{tabular}{|c|c|c|}
\hline $\begin{array}{l}\text { Proximity to UK } \\
\text { Healthcare* }\end{array}$ & $\begin{array}{c}{\left[\mathbf{4 . 0 ] ^ { 8 }}\right.} \\
3.97 \text { miles } \\
\text { Average distances from } 5 \\
\text { middle and } 5 \text { high schools in } \\
\text { Lexington, KY to UKHC }\end{array}$ & $\begin{array}{c}{[\mathbf{0 . 7}]^{9}} \\
0.7 \text { miles between the UK } \\
\text { Main Building and UKHC }\end{array}$ \\
\hline ADHD Rates & $\begin{array}{l}{[6.1]^{10}} \\
\text { Of studied } 4-17 \text { year olds, } \\
6.1 \% \text { take medication for } \\
\text { ADHD in US }\end{array}$ & $\begin{array}{c}{[5.0]^{11}} \\
2-8 \% \text { of college students } \\
\text { across the US }\end{array}$ \\
\hline $\begin{array}{l}\text { Video Game } \\
\text { Experience }^{\#}\end{array}$ & $\begin{array}{l}{[.5]} \\
\text { On average this sample will } \\
\text { have less experience due to } \\
\text { age and video game } \\
\text { comprehension difference. }\end{array}$ & $\begin{array}{l}{[1.0]} \\
\text { On average this sample will } \\
\text { have approximately double } \\
\text { the amount of time based on } \\
\text { the amount of years of video } \\
\text { game playing capability. }\end{array}$ \\
\hline Life Experience & $\begin{array}{c}{[12.5]} \\
\text { Age }(10-15) \text { mean }\end{array}$ & $\begin{array}{c}{[19.5]} \\
\text { Age }(18-21) \text { mean }\end{array}$ \\
\hline $\begin{array}{c}\text { Student/Teacher } \\
\text { Relationship Strength } \\
\text { as Determined by } \\
\text { Class Size* }\end{array}$ & $\begin{array}{l}{[19.2]^{12}} \\
\text { average of } 5 \text { major high } \\
\text { schools in Lexington }\end{array}$ & $\begin{array}{l}{[17.0]^{13,14}} \\
\text { 17:1 Student:faculty ratio at } \\
\text { the University of Kentucky }\end{array}$ \\
\hline Obesity Risk ${ }^{*}$ & $\begin{array}{c}{[15.8]^{15}} \\
15.8 \% \text { of students aged } \\
10-17 \text { had obesity }\end{array}$ & $\begin{array}{l}{[10.2]^{16}} \\
\text { "While obesity rates for } \\
\text { college-age students remains } \\
\text { relatively low (males 10.8\%, } \\
\text { females } 9.6 \% \text { )" }\end{array}$ \\
\hline $\begin{array}{l}\text { Therapeutic dosing } \\
\text { range }^{* \#}\end{array}$ & $\begin{array}{l}{[25]^{17}} \\
\text { Most common stimulant for } \\
\text { UKHC - Dextroamphetamine } \\
\text { For patients ages } 6 \text { and over, } \\
\text { the starting dosage is } \\
\text { typically } 5 \text { mg once or twice a } \\
\text { day. } \\
\text { Mayo Clinic states the daily } \\
\text { dose is typically not over } 30 \text {. } \\
\text { (5mg-30mg) }(30-5=25)\end{array}$ & $\begin{array}{c}{[35]^{18}} \\
\text { Dextroamphetamine - Usual } \\
\text { dose ranges from } 5 \text { to } 40 \mathrm{mg} \\
\text { per day in } 1 \text { to } 3 \text { divided } \\
\text { doses. Subsequent doses } \\
\text { may be given at } 4 \text { to } 6 \text { hours } \\
\text { intervals } \\
(5-40) \\
(40-5=35)\end{array}$ \\
\hline
\end{tabular}




\begin{tabular}{|c|c|c|}
\hline $\begin{array}{c}\text { Sleeping disorder } \\
\text { rate }^{*}\end{array}$ & $\begin{array}{c}{[3.7]^{19}} \\
\text { Across all ages, 3.7\% of } \\
\text { youths had an ICD-9 } \\
\text { diagnosis for a sleep } \\
\text { disorder. } 100,000+\text { sample } \\
\text { size }\end{array}$ & $\begin{array}{c}{[27]^{20}} \\
\text { Twenty-seven percent of } \\
\text { students were at risk for at } \\
\text { least one sleep disorder. } \\
1800+\text { sample size in } \\
\text { southeastern college. }\end{array}$ \\
\hline $\begin{array}{c}\text { Anxiety Disorder } \\
\text { Rate }^{*}\end{array}$ & $\begin{array}{c}\text { [25.12] } \\
\text { Anxiety disorders affect } \\
\text { 25.1\% children between } \\
13 \text { and } 18 \text { years old }\end{array}$ & $\begin{array}{c}\text { [21.9? }]^{22} \\
\text { that within the last } 12 \text { months, } \\
\text { anxiety had affected their } \\
\text { academic performance. }\end{array}$ \\
\hline
\end{tabular}

\begin{tabular}{|c|c|c|}
\hline $\begin{array}{l}\text { Population Density } \\
\text { (For NYC, CHC, ATL) }\end{array}$ & $\begin{array}{c}\mathrm{NYC}-749,424 / 784 \mathrm{~km}^{\wedge} 2= \\
{[\mathbf{9 5 5 . 9}]^{23}} \\
\mathrm{CHC}-100,579 / 591 \mathrm{~km}^{\wedge} 2= \\
{[\mathbf{1 7 0 . 2}]^{24}} \\
\mathrm{ATL}-11,886 / 343 \mathrm{~km}^{\wedge} 2 \\
=[\mathbf{3 4 . 7}]^{25}\end{array}$ & $\begin{array}{c}\text { NYC }-485,646 / 784 \mathrm{~km}^{\wedge} 2= \\
{[\mathbf{6 1 9 . 4}]^{23}} \\
\text { CHC }-69,268 / 591 \mathrm{~km}^{\wedge} 2= \\
{[\mathbf{1 1 6 . 9}]^{24}} \\
\text { ATL }-9,241 / 343 \mathrm{~km}^{\wedge} 2= \\
{[\mathbf{2 6 . 9}]^{25}}\end{array}$ \\
\hline $\begin{array}{l}\text { Location Proximity }^{*} \\
\text { (For NYC, CHC, ATL) }\end{array}$ & $\begin{array}{c}\text { Distance from local NYC } \\
\text { High Schools to NYU Global } \\
\text { Center: }[. \mathbf{8 3 3}]^{\mathbf{2 6}} \\
\text { Local HS/Middle schools to } \\
\text { UChicago Medical Center: } \\
{[1.13]^{28}} \\
\text { Local ATL High schools to } \\
\text { Emory University Hospital: } \\
{\left[\begin{array}{c}\mathbf{3 . 9 7}]^{\mathbf{3 0}}\end{array}\right.}\end{array}$ & $\begin{array}{c}\text { Distance from NYU to NYU } \\
\text { Medical Center: }[\mathbf{0 . 2}]^{27} \\
\text { From UChicago to UChicago } \\
\text { Medical Center: }[\mathbf{0 . 2}]^{29} \\
\text { From Emory University to } \\
\text { Emory University Hospital: } \\
{[\mathbf{0 . 4}]^{31}}\end{array}$ \\
\hline $\begin{array}{c}\text { Student/Teacher } \\
\text { Relationship as } \\
\text { Determined by Class } \\
\text { Size }\end{array}$ & $\begin{array}{c}\text { NYC - [26.4] citywide }{ }^{32} \\
\text { CHC - [29.1] local HS/MS }{ }^{34} \\
\text { ATL - [13] local HS/MS }{ }^{36}\end{array}$ & 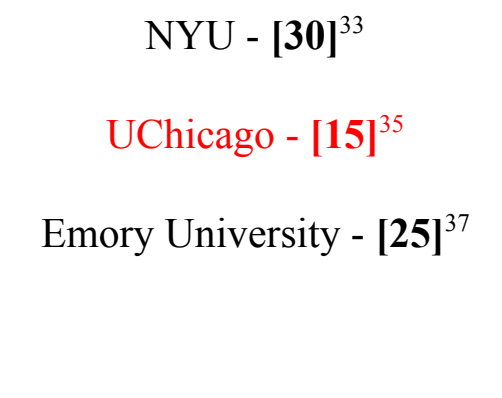 \\
\hline
\end{tabular}

${ }^{*}=$ values between age groups were switched for statistical analysis

\# = heuristic values as described in the text 


\section{A summary of the resulting comparison}

To reiterate, in order to compare the 10-15 year old age group to the 18-21 year old age group, thirteen different characteristics that may have an influence on an ADHD GBT clinical trial were identified. These characteristics were then given values for each age group based upon an in-depth literature search that served to reflect approximate demographics for Lexington, Kentucky when obtainable. If Lexington demographics were unavailable, national demographics were used. If national demographics or outside references were unavailable, a heuristic value was given. Heuristic values are like "rules of thumb", values which are not guaranteed to be the true, real-world value, but are sufficient for immediate goals. ${ }^{15}$ Values that are heuristic are indicated as such within the table above.

Throughout all tables within this study, higher values are designated more valuable to recruitability and IRB approval versus lower values. However, certain category values were switched between age groups due to the higher number being less desirable (e.g. being 10 miles away from the clinical site is less desirable than 5 miles away- so the ' 10 miles away' group received a value of 5 , and vice-versa. The categorical values that were switched between age groups included: location proximity, student/teacher relationship as determined by class size, obesity risk, therapeutic dosing range, sleeping disorder rate, and anxiety disorder rate.

Four experts were recruited to rank the age group characteristics in order of magnitude of effect on subject recruitment and IRB approval influence, with 1 being the least magnitude and 13 being the most. Two of the subjects lacked prior knowledge of the study and were recruited to reduce subjective bias. The results of the survey are shown below in Table 1.

Table 1 - Survey Responses

\begin{tabular}{|c|c|c|c|c|}
\hline \multicolumn{7}{|c|}{ Ranked from 1-13, with 13 being of highest imporatance. } \\
\hline Respondent $\boldsymbol{\text { I1 DL }}$ & Respondent \#2 RL & Respondent \#3 PF & Respondent \#4 CB & AVG \\
\hline 11 & 12 & 12 & 11 & 11.5 \\
\hline 10 & 11 & 13 & 13 & 11.75 \\
\hline 8 & 5 & 10 & 1 & 6 \\
\hline 13 & 13 & 7 & 10 & 10.75 \\
\hline 12 & 10 & 9 & 9 & 10 \\
\hline 9 & 9 & 8 & 8 & 8.5 \\
\hline 6 & 7 & 6 & 7 & 6.5 \\
\hline 4 & 6 & 5 & 3 & 4.5 \\
\hline 7 & 8 & 11 & 12 & 9.5 \\
\hline 1 & 1 & 2 & 5 & 2.25 \\
\hline 5 & 4 & 4 & 2 & 3.75 \\
\hline 2 & 3 & 3 & 4 & 3 \\
\hline 3 & 2 & 1 & 6 & 3 \\
\hline
\end{tabular}

In the first statistical analysis shown below in Table 2, each value for both age groups was converted into a $\mathrm{z}$-score, using the mean and standard deviation of the respective age group, allowing the values to be more comparable to each other. Z-scoring allows us to compare two 
medRxiv preprint doi: https://doi.org/10.1101/19009639; this version posted October 18, 2019. The copyright holder for this preprint (which was not certified by peer review) is the author/funder, who has granted medRxiv a license to display the preprint in perpetuity.

It is made available under a CC-BY-NC 4.0 International license.

values that are taken from different distributions, reducing leverage effects. The 26 respective Z-scores were averaged between the two age groups, resulting in $13 \mathrm{z}$-score values. The values were then weighted by multiplying the average subjective score for that specific characteristic. These 13 'overall score' values give us a subjective reference on the magnitude of effect on subject recruitment and IRB approval influence for the corresponding characteristics. The higher overall score correlates to a stronger influence that the characteristic will have on the clinical trial.

Table 2 - Individual Age Group Values and Z-scores

\begin{tabular}{|c|c|c|c|c|c|}
\hline Column 10-15 aze group Mean & Column $10-15$ age group so & Column 18-21 age youp Mean & Column 18-21 age group SD & Overall Column Mean & Overall Column SD \\
\hline 13.89 & 10.83 & 31.71 & 35,01 & 22.80 & 26.97 \\
\hline & & & & & \\
\hline Characteristic & 10-15 aze group value & $z$-store $10-15$ age group & 18-21 age eroup value & $z$-store $18-21$ age group & Overallil Scare \\
\hline Transportation & 10 & -0.36 & 100 & 1.95 & 9.15 \\
\hline Parent/Guardion Approwal Needed & 0 & -1.28 & 100 & 1.95 & 3.93 \\
\hline Financis Need & 17.8 & 0,36 & 70 & 1.09 & 4.36 \\
\hline Population Density & 21.9 & 0.74 & 23.9 & -0.22 & 2.77 \\
\hline Praximity to UKHC & 0.7 & -1.22 & 4 & -0.79 & 10.05 \\
\hline ADHDRMAS & 6.1 & -0.72 & 5 & -0.76 & 6.30 \\
\hline Videa Game Experience & 0.5 & -1.24 & 1 & -0.88 & 6.87 \\
\hline Ufe Experience & 12.5 & -0.13 & 19.5 & -0.35 & 1.07 \\
\hline Studem/Tescher Relationship & 17 & 0.29 & 19.2 & -0.36 & 0.33 \\
\hline Metabolism/Obesity Risk & 10.2 & -0.34 & 15.8 & -0.45 & 0.89 \\
\hline Therapeutic Dosing Range & 35 & 1.95 & 25 & -0.19 & 3.29 \\
\hline Sleeping Diserder Rate & 27 & 1.21 & 3.7 & -0.80 & 0.62 \\
\hline Anxiety Disonder Rase & 21.9 & 0,74 & 25.1 & -0.19 & 0.83 \\
\hline
\end{tabular}

In the second statistical analysis shown below in Table 3, the characteristic values were once again z-scored by age, however this time they were z-scored using the combined means and standard deviations of both age groups. The new $26 \mathrm{z}$-scores were then multiplied by the average of the subjective scores to produce new subjective magnitudes. Once again, the higher the score, the better the impact on the clinical trial.

Table 3 - Individual Age Group Values and Z-scores - Combined Mean \& Std. Deviation

\begin{tabular}{|c|c|c|c|c|}
\hline Characteristic & I-score $10-15$ year olds & 2 score 18.21 year olds & 10-15 averase score & 18.21 averape scare \\
\hline Transportation & 0.47 & 2.86 & 5.46 & 32.92 \\
\hline ParenV/Guardian Approval Needed & -0.85 & 2.86 & 9.93 & 33.64 \\
\hline Finansiel Need & 0.19 & 1.75 & 1.11 & 10.50 \\
\hline Population Density & -0.03 & 0.04 & 0.36 & 0.44 \\
\hline Proximity to UKHC & -0.82 & 0.70 & 8.19 & 6.97 \\
\hline ADHDRAtes & -0.62 & .0 .66 & 5.26 & 5.61 \\
\hline Video Game Experiente & 0.83 & 0.81 & 5.37 & 5.25 \\
\hline Ufe Experience & -0.38 & -0.12 & 1.72 & 0.55 \\
\hline Skudem/Teacher Relationship & -0.22 & 0.13 & 2.04 & 1.27 \\
\hline Metabolism/Obesity Risk & -0.47 & 0.26 & 1.05 & 0.58 \\
\hline Therapeutic Dosing Range & 0.45 & 0.08 & 1.70 & 0.31 \\
\hline Sleeping Disorder hate & 0.16 & 0.71 & 0.47 & 2.12 \\
\hline Anxiety Disorder Rate & -0.03 & 0.09 & 0.10 & 0.26 \\
\hline & & & 42.77 & 100.42 \\
\hline
\end{tabular}

In the third statistical analysis shown below in Table 4, the higher characteristic values that were deemed optimal for subject recruitability and IRB approval were given a ' 2 ' for the age group value, whereas the characteristic values that produced less optimal results for subject 
medRxiv preprint doi: https://doi.org/10.1101/19009639; this version posted October 18, 2019. The copyright holder for this preprint (which was not certified by peer review) is the author/funder, who has granted medRxiv a license to display the preprint in perpetuity.

It is made available under a CC-BY-NC 4.0 International license.

recruitability and IRB approval were given a ' 1 ' for the respective age group value. Using ' 1 ' and ' 2 ' for values allows for a simpler version of statistical analysis that focuses less on exact numerical values and more on which age group is preferred for the respective category. The age group values are then multiplied by their respective average subjective score. The resulting individual scores are then totaled by age group. The higher overall score is expected to have the optimal impact on subject recruitability and IRB approval. This categorical analysis shows that regardless of using either exact values from a continuous distribution or categorical preference, the result of the 18-21 year old age group being the optimal population remains the same.

Table 4 - Simplified Optimal Age Group Values for Subject Recruitment \& IRB Approval

\begin{tabular}{c|c|c|c|c|}
\cline { 2 - 5 } Characteristic & $10-15$ age group value & $10-15$ score & 18-21 age group value & $18-21$ score \\
\hline Transportation & 1 & 11.5 & 2 & 23 \\
\hline Parent/Guardian Approval Needed & 1 & 11.75 & 2 & 23.5 \\
\hline Financial Need & 1 & 6 & 2 & 12 \\
\hline Population Density & 1 & 10.75 & 2 & 21.5 \\
\hline Proximity to UKHC & 1 & 10 & 1 & 8 \\
\hline ADHD Rates & 2 & 17 & 2 & 13 \\
\hline Video Game Experience & 1 & 6.5 & 1 & 9 \\
\hline Life Experience & 1 & 4.5 & 2 & 9.5 \\
\hline Student/Teacher Relationship & 2 & 19 & 1 & 4.5 \\
\hline Metabolism/Obesity Risk & 1 & 2.25 & 1 & 3.75 \\
\hline Therapeutic Dosing Range & 2 & 7.5 & 2 & 3 \\
\hline Sleeping Disorder Rate & 2 & 6 & & 6 \\
\hline Anxiety Disorder Rate & 1 & 3 & & $\mathbf{1 5}$ \\
\hline
\end{tabular}

In the fourth statistical analysis shown below in Table 5, both of the age group values were divided by the 18-21 year old values to get two respective comparable factors. The new factor values were then multiplied by the corresponding average subjective score to produce concluding values that were totaled for each age group. The higher overall score is expected to have a more optimal expectation for subject recruitability and IRB approval.

Table 5 - Age Group Factorization Combined with Survey Respondent Scores

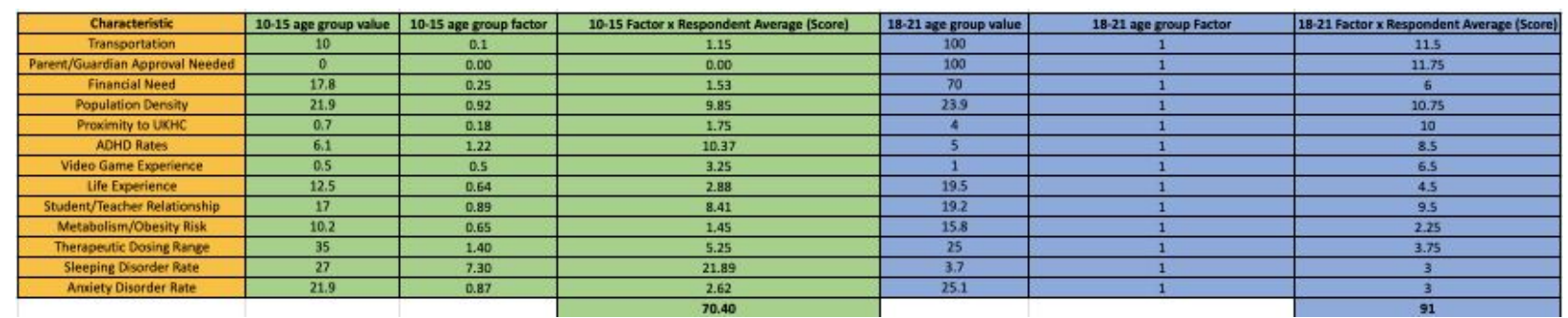

The third and fourth statistical analyses were compared below in Table 6 .

Table 6 - Comparison of Data From Tables 4 and 5

\begin{tabular}{|c|c|c|}
\cline { 2 - 3 } \multicolumn{1}{c|}{} & Scores for Using 132 as factors & Scores using values as factors \\
\hline $10-15$ proup & 115.75 & 70.40 \\
\hline 1821 proup & 157.25 & 91 \\
\hline $1321 / 1015$ & 1.36 & 129 \\
\hline
\end{tabular}


medRxiv preprint doi: https://doi.org/10.1101/19009639; this version posted October 18, 2019. The copyright holder for this preprint (which was not certified by peer review) is the author/funder, who has granted medRxiv a license to display the preprint in perpetuity.

It is made available under a CC-BY-NC 4.0 International license .

\section{\#6 - Sensitivity Analysis and Results}

In order to test the subjective sensitivity of the trade model, the statistical analysis model from Table 3 was used because of its mathematical simplicity. This time however, the average respondent scores were not used, instead results were calculated using individual respondent scores, creating 4 unique respondent results. The respondents included: PharmD/MSPS candidate Dalton Lovins, PharmD/MBA candidate Conner Ball, UK College of Pharmacy pharmaceutical outcomes and policy professor Dr. Patricia Freeman, and UK College of Pharmacy professor and principal investigator for this study, Dr. Robert Lodder. Therefore, the sensitivity test will show how even though different users ranked categories in different positions, the 18-21 year old age group will still succeed in having the highest overall total, making them the optimal group for clinical trial subject recruitability and IRB approval.

\section{Respondent Results Combined with Simplified Optimal Age Group Values}

\begin{tabular}{|c|c|c|c|c|}
\hline \multicolumn{5}{|c|}{ Respondent 1 Result - Dalton Lovins - PharmD/MSPS Candidate } \\
\hline z-score category & $10-15$ age group value & $10-15$ score & 18-21 age group value & 18-21 score \\
\hline Transportation & 1 & 11 & 2 & 22 \\
\hline Parent/Guardian Approval Needed & 1 & 10 & 2 & 20 \\
\hline Financial Need & 1 & 8 & 2 & 16 \\
\hline Population Density & 1 & 13 & 2 & 26 \\
\hline Proximity to UKHC & 1 & 12 & 2 & 24 \\
\hline ADHD Rates & 2 & 18 & 1 & 9 \\
\hline Video Game Experience & 1 & 6 & 2 & 12 \\
\hline Life Experience & 1 & 4 & 2 & 8 \\
\hline Student/Teacher Relationship & 2 & 14 & 1 & 7 \\
\hline Metabolism/Obesity Risk & 1 & 1 & 2 & 2 \\
\hline Therapeutic Dosing Range & 2 & 10 & 1 & 5 \\
\hline Sleeping Disorder Rate & 2 & 4 & 1 & 2 \\
\hline \multirow[t]{2}{*}{ Anxiety Disorder Rate } & 1 & 3 & 2 & 6 \\
\hline & & 114 & & 159 \\
\hline
\end{tabular}

\begin{tabular}{|c|c|c|c|c|}
\hline \multicolumn{5}{|c|}{ Respondent 2 Result - Dr. Robert Lodder - UK College of Pharmacy Professor, PI of Clinical Study } \\
\hline 2-score category & $10-15$ age group value & $10-15$ score & $18-21$ ase group value & 18-21 score \\
\hline Transportation & 1 & 12 & 2 & 24 \\
\hline Parent/Guardian Approval Needed & 1 & 11 & 2 & 22 \\
\hline Financial Need & 1 & 5 & 2 & 10 \\
\hline Population Density & 1 & 13 & 2 & 26 \\
\hline Proximity to UKHC & 1 & 10 & 2 & 20 \\
\hline ADHD Rates & 2 & 18 & 1 & 9 \\
\hline Video Game Experience & 1 & 7 & 2 & 14 \\
\hline Life Experience & 1 & 6 & 2 & 12 \\
\hline Student/Teacher Relationship & 2 & 16 & 1 & 8 \\
\hline Metabolism/Obesity Risk & 1 & 1 & 2 & 2 \\
\hline Therapeutic Dosing Range & 2 & 8 & 1 & 4 \\
\hline Sleeping Disorder Rate & 2 & 6 & 1 & 3 \\
\hline \multirow[t]{2}{*}{ Anwiety Disorder Rate } & 1 & 2 & $\overline{2}$ & 4 \\
\hline & & 115 & & 158 \\
\hline
\end{tabular}


medRxiv preprint doi: https://doi.org/10.1101/19009639; this version posted October 18, 2019. The copyright holder for this preprint (which was not certified by peer review) is the author/funder, who has granted medRxiv a license to display the preprint in perpetuity.

It is made available under a CC-BY-NC 4.0 International license.

\begin{tabular}{|c|c|c|c|c|}
\hline \multicolumn{5}{|c|}{ Respondent 3 Result - Dr. Patricia Freeman - Pharmaceutical Outcomes and Policy Expert } \\
\hline z-score category & $10-15$ age group value & 10-15 score & 18-21 age group value & $18-21$ score \\
\hline Transportation & 1 & 12 & 2 & 24 \\
\hline Parent/Guardian Approval Needed & 1 & 13 & 2 & 26 \\
\hline Financial Need & 1 & 10 & 2 & 20 \\
\hline Population Density & 1 & 7 & 2 & 14 \\
\hline Proximity to UKHC & 1 & 9 & 2 & 18 \\
\hline ADHD Rates & 2 & 16 & 1 & 8 \\
\hline Video Game Experience & 1 & 6 & 2 & 12 \\
\hline Life Experience & 1 & 5 & 2 & 10 \\
\hline Student/Teacher Relationship & 2 & 22 & 1 & 11 \\
\hline Metabolism/Obesity Risk & 1 & 2 & 2 & 4 \\
\hline Therapeutic Dosing Range & 2 & 8 & 1 & 4 \\
\hline Sleeping Disorder Rate & 2 & 6 & 1 & 3 \\
\hline Anxiety Disorder Rate & 1 & 1 & 2 & 2 \\
\hline & & 117 & & 156 \\
\hline
\end{tabular}

\begin{tabular}{|c|c|c|c|c|}
\hline \multicolumn{5}{|c|}{ Respondent 4 Result - Conner Ball - Pharmd/MBA Candidate } \\
\hline z-score category & $10-15$ age group value & $10-15$ score & 18-21 age group value & 18-21 score \\
\hline Transportation & 1 & 11 & 2 & 22 \\
\hline Parent/Guardian Approval Needed & 1 & 13 & 2 & 26 \\
\hline Financial Need & 1 & 1 & 2 & 2 \\
\hline Population Density & 1 & 10 & 2 & 20 \\
\hline Proximity to UKHC & 1 & 9 & 2 & 18 \\
\hline ADHD Rates & 2 & 16 & 1 & 8 \\
\hline Video Game Experience & 1 & 7 & 2 & 14 \\
\hline Life Experience & 1 & 3 & 2 & 6 \\
\hline Student/Teacher Relationship & 2 & 24 & 1 & 12 \\
\hline Metabolism/Obesity Risk & 1 & 5 & 2 & 10 \\
\hline Therapeutic Dosing Range & 2 & 4 & 1 & 2 \\
\hline Sleeping Disorder Rate & 2 & 8 & 1 & 4 \\
\hline \multirow[t]{2}{*}{ Anxiety Disorder Rate } & 1 & 6 & 2 & 12 \\
\hline & & 117 & & 156 \\
\hline
\end{tabular}

- In order to test the location sensitivity of the trade model, we have included results from New York, NY., Chicago, IL., and Atlanta, GA. Even with a population as dense as these 3 major cities, the overall outcome is very similar with the 18-21 year old age group being the optimal treatment group.

\section{New York City, New York Model}

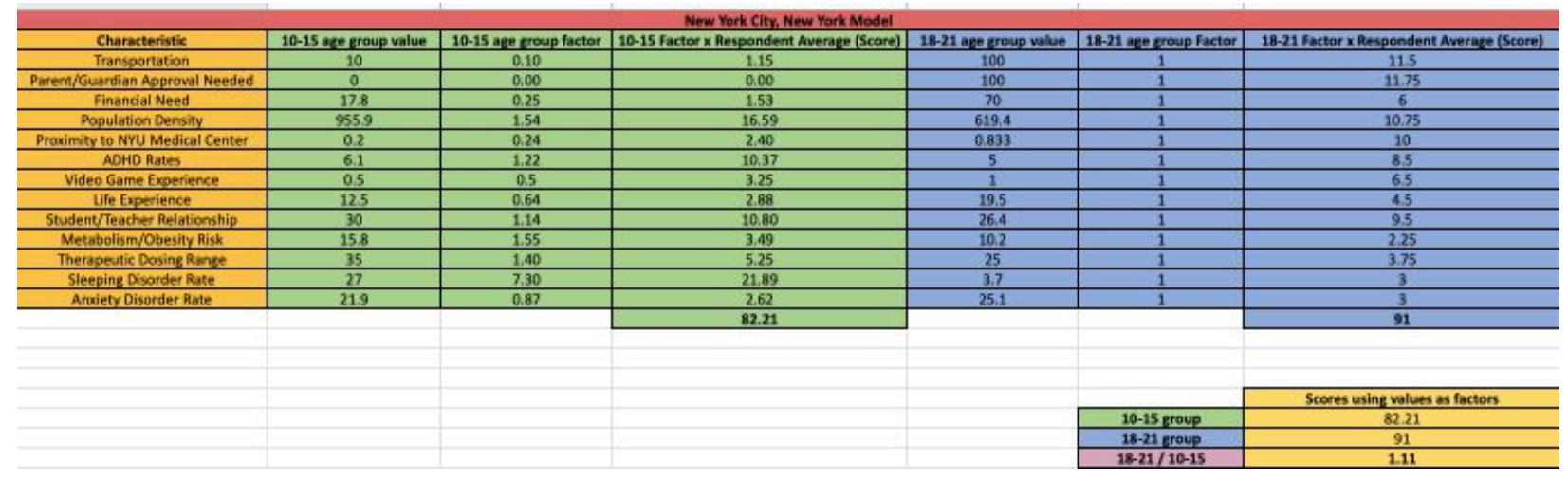




\section{Chicago, Illinois Model}

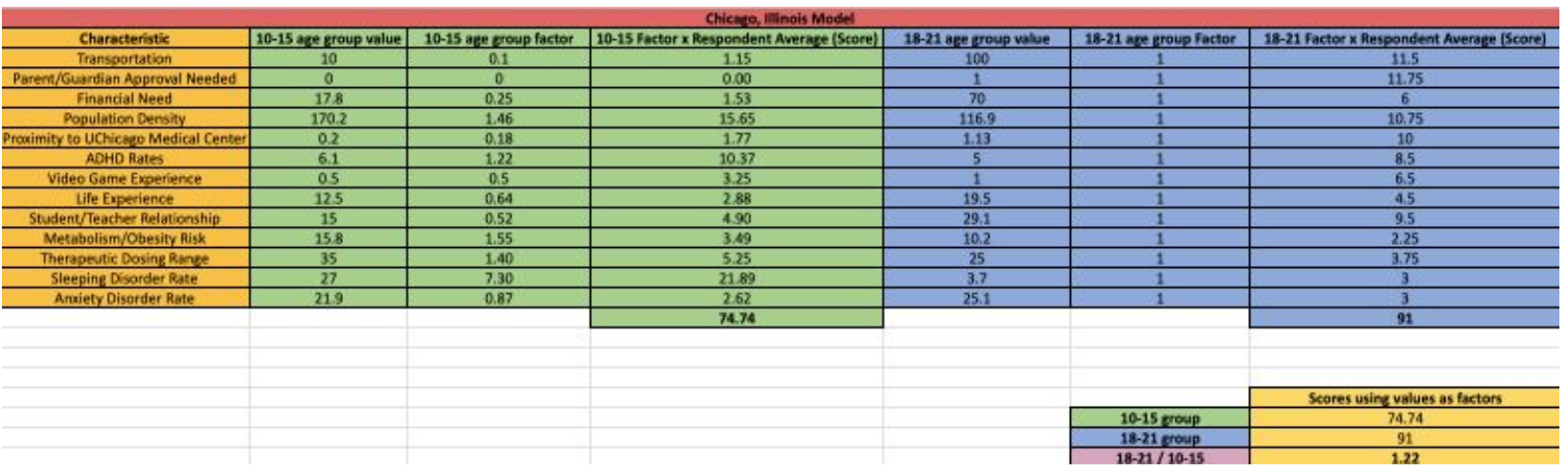

Atlanta, Georgia Model

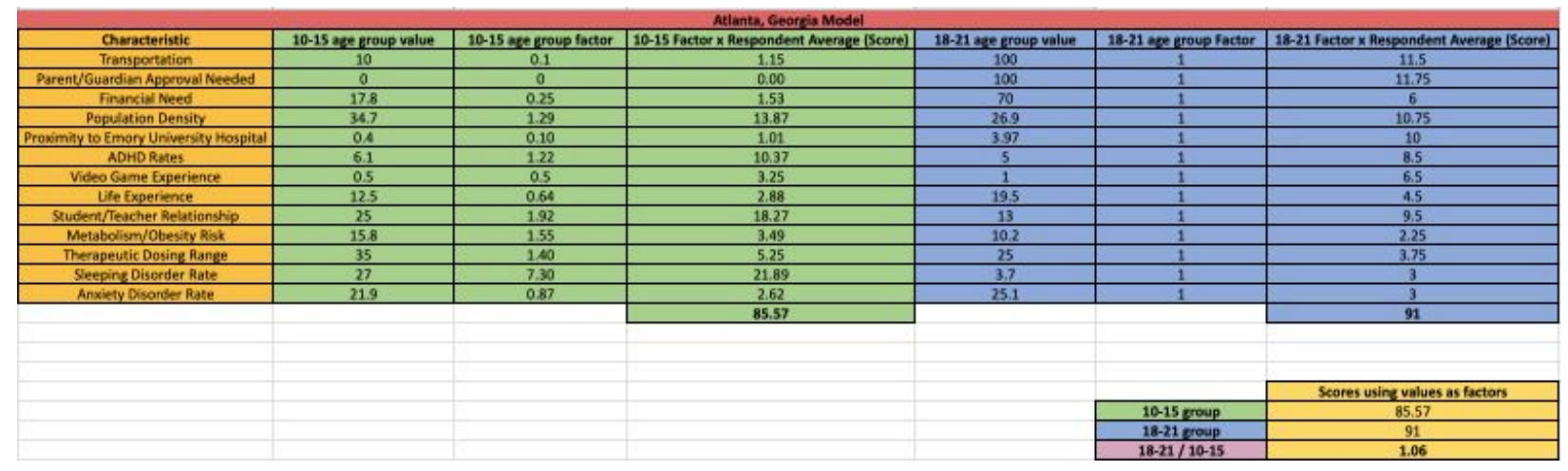

\section{Conclusion, Adoption, and Further Analysis}

The overall conclusion of this study is that the 18-21 year old age group in Lexington, Kentucky is the optimal population for future GBT/ADHD clinical studies.

These data and analyses will be used for the future adoption of the 18-21 year old age group for examining whether GBT has an effect on ADHD symptoms. For the next trial, a maximum of 60 days will be allotted to recruiting at least 16 subjects in order to draw scientific conclusions regarding the relationship between combination Game Based Therapy with pharmacological treatment and ADHD symptoms.

An unexplored option regarding alternative trade studies includes separating the initial survey question, which was, "Rank the age group characteristics in order of magnitude of effect on subject recruitment and IRB approval influence, with 1 being the least magnitude and 13 being the most," into two separate questions. In turn, one question would ask solely about the magnitude of effect on subject recruitability and the other question would ask solely about the magnitude of effect on IRB approval. This analysis would have been beneficial in comparing the effect on survey responses, and subsequently the outcomes of similarly structured statistical analyses. 


\section{Supplementary Material}

A special thanks to those who participated in the clinical trial characteristics ranking. Dr. Lodder is the principal investigator for the initial GBT trial for 10-15 year olds and has been constantly utilized for consults regarding this paper's purpose, execution, and reviewal. Dr. Patricia Freeman is a current pharmaceutical outcomes and policy professor at the University of Kentucky College of Pharmacy. Conner Ball is a current MBA candidate at the University of Kentucky.

Dr. Robert Lodder - UKCOP Professor

Dr. Patricia Freeman - UKCOP Professor

Conner Ball - PharmD/MBA candidate 2021

Dr. Penni Black - UKCOP Professor

\section{References}

1. American Psychiatric Association. (2013). Diagnostic and statistical manual of mental disorders (5th ed). Arlington, VA: American Psychiatric Publishing.

2. "Attention Deficit Hyperactivity Disorder." MentalHealth. US Department of Health and Human Services. 8 August 2017.

https://www.mentalhealth.gov/what-to-look-for/behavioral-disorders/adhd

3. "Addressing Diagnosis and Treatment Gaps in Adults with

Attention-Deficit/Hyperactivity Disorder." The Primary Care Companion for CNS

Disorders. Physicians Postgraduate Press, Inc. 7 September 2017.

https://www.psychiatrist.com/PCC/article/Pages/2017/v19n05/17nr02153.aspx

4. Kessler RC, Adler L, Barkley R, et al. The prevalence and correlates of adult ADHD in the United States: results from the National Comorbidity Survey Replication. Am J Psychiatry. 2006;163(4):716-723.

5. Spencer TJ, Biederman J, Mick E. Attention-deficit/hyperactivity disorder: diagnosis, lifespan, comorbidities, and neurobiology. Ambul Pediatr. 2007;7(suppl 1):73-81.

6. Adler LA. Clinical presentations of adult patients with ADHD. J Clin Psychiatry. 2004;65(suppl 3):8-11.

7. Manos MJ. Psychosocial therapy in the treatment of adults with attention-deficit/hyperactivity disorder. Postgrad Med. 2013;125(2):51-64.

8. Rutledge, K. J., van den Bos, W., McClure, S. M., \& Schweitzer, J. B. (2012). Training cognition in ADHD: current findings, borrowed concepts, and future directions. Neurotherapeutics, 9(3), 542-558.

9. Molina, B. S., Hinshaw, S. P., Swanson, J. M., Arnold, L. E., Vitiello, B., Jensen, P. S., ... \& Elliott, G. R. (2009). The MTA at 8 years: prospective follow-up of children treated 
for combined-type ADHD in a multisite study. Journal of the American Academy of Child \& Adolescent Psychiatry, 48(5), 484-500.

10. Pelham, W. E., \& Gnagy, E. M. (1999). Psychosocial and combined treatments for ADHD. Developmental Disabilities Research Reviews, 5(3), 225-236.

11. Diamond, A. (2013). Executive functions. Annual review of psychology, 64, 135-168.

12. "What is Minecraft?" Accessed October 30, 2017. http://parentinfo.org/article/what-isminecraft

13. Tiitto, M. 2019. Therapeutic Video Games and the Simulation of Executive Function Deficits in ADHD. University of Kentucky College of Pharmacy. Lexington, Kentucky.

14. Kossiakoff, A., Sweet, W. (2003) Systems Engineering Principles and Practice. Hoboken, New Jersey. John Wiley and Sons.

15. Heuristic Approaches to Problem Solving. https://www.101 computing.net/heuristic-approaches-to-problem-solving/

\section{Statistical Analysis Chart References}

Transportation References:

1. Biking: Survey: 100 Million Americans Bike Each Year, But Few Make it a Habit. https://usa.streetsblog.org/2015/03/04/survey-100-million-americans-bike-each-year-butfew-make-it-a-habit/

2. Graduated Driver Licensing Program. Drive.KY.gov. https://drive.ky.gov/driver-licensing/Pages/Graduated-Driver-Licensing-Program.aspx

3. University of KY Campus bus routes

https://www.uky.edu/transportation/bus/campusshuttles

Parental Approval Requirement:

4. Field, MJ. Ethical Conduct of Clinical Research involving Children. Institute of Medicine (US) Committee on Clinical Research Involving Children.https://www.ncbi.nlm.nih.gov/books/NBK25560/

Financial Need Rate:

5. Data Tables and Tools ACS. https://www.census.gov/acs/www/data/data-tables-and-tools/

6. A Look at the Shocking Student Loan Debt for 2019. StudentLoanHero. Feb. 9, 2019. https://studentloanhero.com/student-loan-debt-statistics/ 
Population Density for Lexington

7. Current Lexington, KY Population, Demographics, and stats in 2019, 2018. US Census Data. https://suburbanstats.org/population/kentucky/how-many-people-live-in-lexington

Proximity to UKHC

8. Google Maps - Distance from Morton middle, Windburn middle, Southern Middle, Crawford Middle, Tates Creek Middle, Sayre, Henry Clay, Lex Cath, Trinity Christian Academy Upper School, and Paul Dunbar to UK Chandler Hospital https://www.google.com/maps

9. UK Main Building distance to UK Chandler Hospital https://www.google.com/maps

ADHD Rates - Kentucky

10. CDC. 2011 data. https://www.cdc.gov/ncbddd/adhd/stateprofiles/stateprofile_kentucky.pdf

11. Dupaul GJ, Weyandt LL, O’Dell SM, et al. College students with ADHD: Current status and future directions. J Atten Disord. 2009;13:234-250. doi: 10.1177/1087054709340650

Student Teacher Relationship

12. 17. 2019 Largest Public High Schools in Kentucky. https://www.niche.com/k12/search/largest-public-high-schools/s/kentucky/

13. University of Kentucky FAQs - Average Class size http://students.ca.uky.edu/faqs

14. Why Students Don't Attend Office Hours https://www.teachingprofessor.com/topics/for-those-who-teach/students-dont-attend-offic e-hours/

Obesity Risk

15. Childhood Obesity Trends - The State of Obesity. https://www.stateofobesity.org/childhood-obesity-trends/

16. Serious Games for Diabetes, Obesity, and Healthy Lifestyle: Using an Alternate Reality Game to Increase Physical Activity and Decrease Obesity Risk in College Students. https:/www.ncbi.nlm.nih.gov/pmc/articles/PMC3440154/

Therapeutic Dosing Range

17. https:/www.mayoclinic.org/drugs-supplements/dextroamphetamine-and-amphetamine-or al-route/proper-use/drg-20071758

18. Dextroamphetamine. https://www.ncbi.nlm.nih.gov/books/NBK507808/ 
Sleeping Disorder

19. Prevalence of Diagnosed Sleep Disorders in Pediatric Primary Care Practices. https://www.ncbi.nlm.nih.gov/pmc/articles/PMC3089951/

20. The Prevalence of Sleep Disorders in College Students: Impact on academic Performance.

https://www.csus.edu/faculty/M/fred.molitor/docs/Sleep\%20and\%20Academic\% $\% 20$ Perfo rmance.pdf

Anxiety Disorder Rate

21. Facts \& Statistics - Anxiety and Depression Association of America. https://adaa.org/about-adaa/press-room/facts-statistics

22. Mental Health Matters: Anxiety and Depression - BU Today. http://www.bu.edu/articles/2016/college-students-anxiety-and-depression

Population Density for New York City, NY

23. Current NYC, NY Population, Demographics, and stats in 2019, 2018. https://suburbanstats.org/population/new-york/how-many-people-live-in-new-york

Population density for Chicago, IL

24. Current Chicago IL Population, Demographics, and stats in 2019, 2018. https://suburbanstats.org/population/illinois/how-many-people-live-in-chicago

Population Density for Atlanta, GA

25. Current Atlanta, GA Population, Demographics, and stats in 2019, 2018. https://suburbanstats.org/population/georgia/how-many-people-live-in-atlanta

Proximity to NYU Medical Center

26. Average distance from Manhattan Village Academy, Norman Thomas HS, LREI Lower and Middle School to NYU

27. Distance between NYU to NYU Langone Medical Center

Proximity to UChicago Medical Center

28. Average distance from University of Chicago Charter School, University of Chicago Laboratory Schools, and King College Prep High School to UChicago Medical Center.

29. Distance between UChicago to UChicago Medical Center 
Proximity to Emory University Hospital

30. Average distance from Druid Hills High School, Ben Franklin Academy, Samuel Inman Middle School.

31. Distance between Emory University to Emory University Hospital

Student/Teach Relationship for New York, NY

32. New York City citywide average class size https://infohub.nyced.org/docs/default-source/default-document-library/2018-19_novemb er_class_size_report_-_webdeck_-_11-14-18.pdf?Status $=$ Temp\&sfvrsn=c46ddc95_2

33. NYU average class size https://www.collegedata.com/college/New-York-University?tab=profile-overview-tab

Student/Teacher Relationship for Chicago, IL

34. Chicago Public Schools average class size https://cps.edu/About_CPS/At-a-glance/Pages/Stats_and_facts.aspx

35. UChicago average class size https://www.collegedata.com/college/University-of-Chicago?tab=profile-overview-tab

Student/Teacher Relationship for Atlanta, GA

36. Atlanta Public Schools average class size https://www.publicschoolreview.com/georgia/atlanta-public-schools/1300120-school-dist rict

37. Emory University average class size http://www.emory.edu/home/academics/faculty/index.html 